\title{
CONGENITAL CORONARY ARTERY-RIGHT VENTRICULAR FISTULA CORRECTED SURGICALLY*
}

\author{
BY \\ MARIA SERRATTO AND PAUL KEZDI \\ From the Heart Station and the Department of Medicine, Northwestern University Medical School and Chicago Wesley \\ Memorial Hospital, Chicago, Illinois, U.S.A.
}

Anomalous communication of one or both coronary arteries and a cardiac chamber was described for the first time by Cayla in 1885. Recently, the introduction of selective angiocardiography and the possibility of satisfactory repair by relatively simple surgical procedures have furthered the interest in the syndrome. Most of the patients diagnosed during life and operated upon were children (Gasul et al., 1960; Abbott, Rivarola, and Logue, 1961; Cooley and Ellis, 1962; Soulié et al., 1963; Michaud et al., 1963; Effler and Welti, 1963).

The patient presented here is unusual in that he was a middle-aged man with a congenital fistula between the right coronary artery and the right ventricle, which was successfully treated by operation.

\section{Case Report}

A 33-year-old white accountant was admitted to Chicago Wesley Memorial Hospital in May 1961, for evaluation of a heart murmur and cardiomegaly, which had been present since birth. His past history revealed an episode of subacute bacterial endocarditis in 1946, successfully treated with penicillin in another hospital. In 1955 and again in 1956, he was admitted to the hospital for "kidney infection", and in 1957 he underwent right inguinal hernia repair. The patient had been entirely asymptomatic throughout his life and had never limited his physical activity. However, he was not accepted for military service, and life insurance had been denied to him because of his cardiac status.

On physical examination, he appeared well developed, obese, not in acute or chronic distress. The respiratory rate was 20 per minute, pulse rate 76 per minute, and blood pressure $130 / 70 \mathrm{~mm}$. $\mathrm{Hg}$. There was no præcordial asymmetry. The point of maximal impulse was strong and diffuse and was located at the sixth intercostal space at the anterior axillary line. The cardiac dullness extended $3.5 \mathrm{~cm}$. to the right of the sternum. There was a significant left parasternal heave and a systolic thrill was palpable at the third left intercostal space at the sternal margin. In the same area, a loud (grade 4 out of 6) systolic and an early-tomid medium intensity (grade 3 out of 6) diastolic murmur were present, which radiated widely over the anterior præcordium. The second sound was normally split. The peripheral pulses were normal.

The chest radiograph showed increased pulmonary vascularity. The transverse cardiac diameter was 42 per cent above the normal and the enlargement appeared to be biventricular. There was marked increase in the diameter of the main pulmonary artery segment. The electrocardiogram showed incomplete right bundle-branch block pattern, and there was left axis deviation $\left(-15^{\circ}\right)$ and increased voltage in the præcordial leads (RV6+SV1=46 mm.) suggesting left ventricular hypertrophy (Fig. 1). The phonocardiogram confirmed the presence of the systolic and diastolic murmurs. Right heart catheterization disclosed a significant increase in oxygen content at the ventricular level. The left-to-right shunt was $3.91 . / \mathrm{min} . / \mathrm{m} .{ }^{2}$ with a systemic output of $2 \cdot 31 . / \mathrm{min} . / \mathrm{m}^{2}$. The right ventricular systolic pressure was moderately raised $(43 / 2 \mathrm{~mm}$. $\mathrm{Hg})$ and a gradient of $23 \mathrm{~mm}$. Hg was present across the pulmonary valve: this was interpreted as due to the increased flow. Total pulmonary resistance was $441 \mathrm{dynes} \mathrm{sec.} / \mathrm{cm} .{ }^{-5}$. Retrograde aortography from the right brachial artery with injection into the left ventricle showed no ventricular septal defect but instead demonstrated a very dilated right coronary artery and ascending aorta (Fig. 2).

* This work was supported in part by the USPH Grant No. HE 06371-03. 


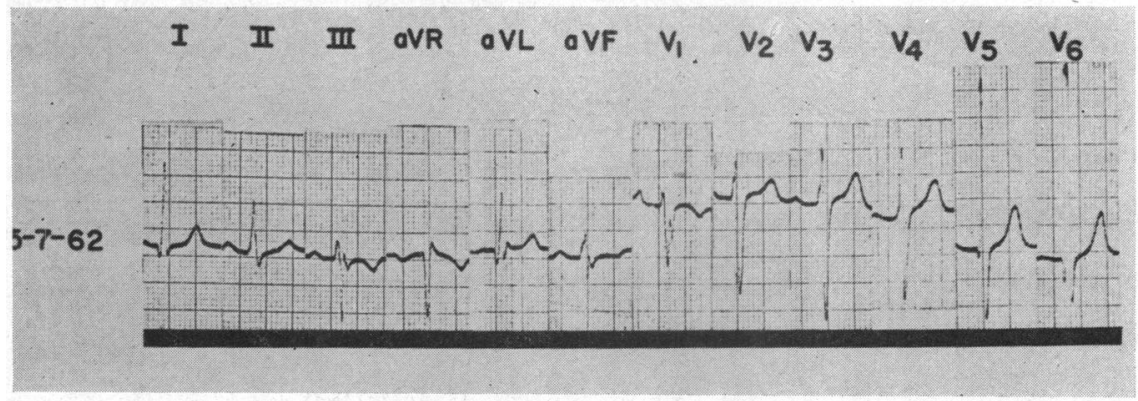

FIG. 1.-Electrocardiogram before operation showing increased voltage in V1 and V6 $(\mathrm{RV} 6+\mathrm{SV} 1=$ $46 \mathrm{~mm}$.), and left axis deviation $\left(-15^{\circ}\right)$.

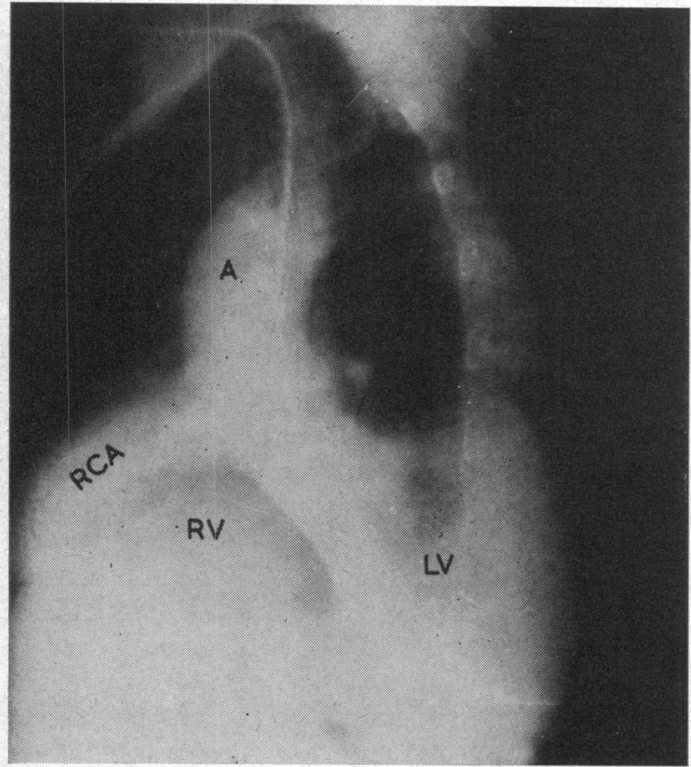

Fig. 2.-Retrograde aortogram demonstrating the very dilated right coronary artery and ascending aorta. Left anterior oblique view. $R V=$ right ventricle, $L V=$ left ventricle, $R C A=$ dilated right coronary artery, $\mathbf{A}=$ aorta.

voltage in the præcordial leads was now normal. The chest radiography showed a decrease in the transverse cardiac diameter to 22 per cent above the normal.

\section{Discussion}

According to Edwards (1958) the anomalies of the coronary arterial system may be divided into three groups: (1) minor anomalies of origin or distribution of no importance under usual circumstances; (2) anomalies secondary to other cardiac malformations; and (3) primary anomalies of origin or of communication that are of major significance. In this group, maldevelopment may produce two types of abnormal arteriovenous communications. In the first, a coronary artery originates from the pulmonary trunk with reversal of the blood flow in this vessel which is fed by anastomosis from the other coronary artery (Edwards, 1958). In the second variety, an arrest or 
faulty differentiation of the embryonal intramyocardial sinusoids is responsible for the communication between a coronary artery and a right or left-sided cardiac structure (Edwards, Gladding, and Weir, 1958). In this report, we are concerned only with the second variety of Edwards' third group of coronary arterial abnormalities, since the pathology in our patient consisted of an anomalous communication between the right coronary artery and the right ventricle.

The primary functional disturbance of a coronary artery fistula is the "run-off" of blood from the coronary arterial system, with the portion of myocardium supplied by the vessels beyond the communication receiving less blood than normal. In fact most of the blood is diverted away from the myocardial capillaries, which represent a zone of high resistance, to the low-resistance anomalous channel. However, one can assume that an efficient collateral circulation supplying the critical area develops early in life since myocardial ischæmia as a complication of the syndrome has been reported in only a few instances (Knoblich and Rawson, 1956; Valdivia, Rowe, and Angevine, 1957; Edwards et al., 1958) and never in infants. Our patient never complained of angina. The transitory electrocardiographic changes after operation are a common finding in operations involving the heart and are probably due to pericardial injury and not secondary to this anomaly. The majority of the cases with coronary artery-right ventricular fistulæ reported by others have had continuous murmurs. The diastolic component was reported to be louder in 4 out of 5 patients of Gasul et al. (1960). Separate systolic and diastolic murmurs have also been described. Since it is expected that flow through the fistula is greatest during diastole, the diastolic component of the murmur should be louder. However, in our case, the systolic component was louder. It appears that there was a superimposed ejection murmur which made the systolic murmur more prominent. This explanation is supported by the fact that there was a $23 \mathrm{~mm}$. Hg systolic gradient at the pulmonary valve during cardiac catheterization. Since the fistula entered the apical region of the right ventricle, shunting was probably less during systole because of narrowing of the fistulous opening during contraction of the myocardium. Though the patient was asymptomatic, his right ventricular systolic pressure and total pulmonary resistance were moderately raised due to the large left-to-right shunt. In consequence of the overload of all cardiac chambers, the heart was very enlarged, including the pulmonary trunk. Dilatation of the right coronary artery and of the ascending aorta was well demonstrated by selective angiocardiography. This latter feature has been emphasized by Gasul et al. (1960) as one of the leading characteristics of the syndrome, short of the demonstration of the dilated coronary artery draining into a cardiac chamber.

Patients with this condition seem to tolerate the increased cardiac load (which in some cases may be quite large) extremely well (Gasul et al., 1960; Neufeld et al., 1961 ; Carmichael and Davidson, 1961). However, recently Steinberg, Baldwin, and Dotter (1958) described 5 adult patients who died in congestive heart failure produced by a similar anomalous communication. Congestive heart failure may be a prominent feature also in infancy (Sanger, Taylor, and Robicsek, 1959; Cooley and Ellis, 1962; Braudo et al., 1962) and be the cause of death. Other complications include pulmonary hypertension (Davison, McKracken, and McIlveen, 1955; Neill and Mounsey, 1958; Bosher et al., 1959) and bacterial endoarteritis (present case; Trevor, 1911; Jacobi and Heinrich, 1933; Vela, Velasques, and Fuenmoyor, 1951; Sanger et al., 1959). Therefore, the syndrome does not appear to be as benign as the early investigators thought.

The current view regarding therapy holds that the presence of either clinical manifestations or significant laboratory findings calls for surgical repair of the lesion. This has been accomplished in 41 patients to date (Sondergaard, 1955; Davis et al., 1956; Johnson, personal communication to Davis et al., 1956; Mozen, 1956; Morrow, personal communication to Edwards et al., 1958; Neill and Mounsey, 1958; Bosher et al., 1959; Grob and Kolb, 1959; Kittle, 1959; Sanger et al., 1959; Swan et al., 1959; Diehl, 1960; Gasul, et al., 1959; Zuhdi et al., 1960; Carmichael and Davidson, 1961 ; Dubost, Chevrier, and Metianu, 1961 ; Engle et al., 1961 ; McIntosh et al., 1961; Neufeld et al., 1961; Barcia et al., 1962; Braudo et al., 1962; Cooley and Ellis, 1962; Papaioannou et al., 1962; Effler and Welti, 1963; Michaud et al., 1963; Soulié et al., 1963) with only 2 reported deaths (Bosher et al., 1959; Michaud et al., 1963): both occurred in small critically ill children, one of whom had an 
associated patent ductus arteriosus. Three patients in whom interruption of the fistula was obtained by ligation of the coronary artery developed myocardial infarction (Swan et al., 1959; Cooley and Ellis, 1962; Michaud et al., 1963). In a fourth patient cardiac arrest occurred four hours after operation (Cooley and Ellis, 1962).

Therefore, closure of the fistula without interruption of the continuity of the parent vessel was advocated and has been successfully accomplished in this patient.

\section{Summary}

A case of right coronary artery-right ventricular fistula occurring in a middle-aged asymptomatic man is reported. Physiological study was prompted by the detection of an unexplained cardiomegaly and heart murmur. Correction of the lesion was accomplished by direct vision closure of the fistula with maintenance of the parent coronary artery patency. The patient made a complete recovery.

Recent publications on the subject and current therapeutic orientation are discussed.

The operation in this patient was performed by Dr. Arthur De Boer, staff surgeon of Chicago Wesley Memorial Hospital.

\section{References}

Abbott, O. A., Rivarola, C. H., and Logue, R. B. (1961). Surgical correction of coronary arteriovenous fistula. J. thorac. Surg., 42, 660 .

Barcia, A., Kincaid, O. W., Swan, H. J. C., Weidman, W. H., and Kirklin, J. W. (1962). Coronary artery-to-right ventricle communication: Report of two cases studied by selective angiocardiography. Proc. Mayo Clin., 37, 623 .

Bosher, L. H., Vasli, S., McCue, C. M., and Belter, L. F. (1959). Congenital coronary arteriovenous fistula associated with large patent ductus. Circulation, 20, 254

Braudo, J. L., Javett, S. N., Zion, M. M., and Adler, D. I. (1962). Congenital coronary arteriovenous fistula. Brit. med. J., 1, 601.

Carmichael, D. B., and Davidson, D. G. (1961). Congenital coronary arteriovenous fistula. Amer. J. Cardiol., 8, 846.

Cayla, A. (1885). Malformation congénital du coeur.-Canal faisant communiquer l'extrémité du ventricule droit avec l'origine de l'aorte. Progr. méd. (Paris), 2 ser., 2, 121.

Cooley, D. A., and Ellis, P. R. (1962). Surgical considerations of coronary arterial fistula. Amer. J. Cardiol., 10, 467.

Davis, C., Jr., Dillon, R. F., Fell, E. H., and Gasul, B. M. (1956). Anomalous coronary artery simulating patent ductus arteriosus. J. Amer. med. Ass., 160, 1047.

Davison, P. H., McKracken, B. H., and Mcllveen, D. J. S. (1955). Congenital coronary arterio-venous aneurysm. Brit. Heart J., 17, 569.

Diehl, A. (1960). Personal communication to Gasul et al. (1960).

Dubost, C., Chevrier, J. L., and Metianu, C. (1961). Congenital communication between the right coronary artery and the right atrium. J. cardiovasc. Surg. (Torino), $2,60$.

Edwards, J. E. (1958). Anomalous coronary arteries with special reference to arteriovenous-like communications. (Editorial). Circulation, 17, 1001.

-, Gladding, T. C., and Weir, A. B., Jr. (1958). Congenital communication between the right coronary artery and the right atrium. J. thorac. Surg., 35, 662.

Effler, D. B., and Welti, H. (1963). A propos d'une fistule artério-veineuse entre artère coronaire gauche et ventricule droit. Arch. Mal. Coeur, 56, 164.

Engle, M. A., Goldsmith, E. I., Holswade, G. R., Goldberg, H. P., and Glenn, F. (1961). Congenital coronary arteriovenous fistula. New Engl. J. Med., 264, 856.

Gasul, B. M., Arcilla, R. A., Fell, E. H., Lynfield, J., Bicoff, J. P., and Luan, L. L. (1960). Congenital coronary arteriovenous fistula: Clinical, phonocardiographic, angiocardiographic and hemodynamic studies in five patients. Pediatrics, 25, 531.

-, Fell, E. H., Moreano, M., and Weinberg, M., Jr. (1959). Congenital coronary arteriovenous aneurysm. Clinical, angiocardiographic, and physiologic findings on 3 patients with successful surgical correction. Arch. Surg., 78, 203.

Grob, M., and Kolb, E. (1959). Congenital aneurysm of the coronary artery. Arch. Dis. Childh., 34, 8.

Jacobi, M., and Heinrich, A. (1933). Congenital aorticoventricular fistula with engrafted acute suppurative endocarditis. Amer. J. med. Sci., 186, 364.

Johnson, J. Quoted by Davies et al. (1956).

Kittle, C. F. (1959). Discussion. Arch. Surg., 78, 204.

Knoblich, R., and Rawson, A. J. (1956). Arteriovenous fistula of the heart. Amer. Heart J., 52, 474.

McIntosh, H. D., Sleeper, J. G., Thompson, H. K., Jr., Sealy, W. C., and Young, W. G., Jr. (1961). Preoperative evaluation of a continuous murmur in the chest. Arch. Surg., 82, 74. 
Michaud, P., Froment, R., Viard, H., Gravier, J., and Verney, R. N. (1963). Les fistules coronaro-ventriculaires droites. Arch. Mal. Caur, 56, 143.

Morrow, A. G. Quoted by Edwards et al. (1958).

Mozen, H. E. (1956). Congenital cirsoid aneurysm of a coronary artery with associated arterio-atrial fistula, treated by operation: A case report. Ann. Surg., 144, 215.

Neill, C., and Mounsey, P. (1958). Auscultation in patent ductus arteriosus: With a description of two fistulæ simulating patent ductus. Brit. Heart J., 20, 61.

Neufeld, H. N., Lester, R. G., Adams, P., Anderson, R. C., Lillehei, C. W., and Edwards, J. E. (1961). Congenital communication of a coronary artery with a cardiac chamber or the pulmonary trunk. ("Coronary artery fistula".) Circulation, 24, 171.

Papaioannou, A., Agorogiannis, S., Nihoyanopoulos, J., and Lazzaridis, D. (1962). Congenital coronary artery fistula. Amer. J. Cardiol., 10, 588.

Sanger, P. W., Taylor, F. H., and Robicsek, F. (1959). The diagnosis and treatment of coronary arteriovenous fistula. Surgery, 45, 344.

Sondergaard, T. (1955). In Henry Ford Hospital. International Symposium on Cardiovascular Surgery, ed. C. R. Lam, p. 492. Saunders, Philadelphia.

Soulié, P., Mathey, J., Di Mattéo, J., Vernant, P., Piton, A., Bouchard, F., and Neveux, J. Y. (1963). Communications congénitales entre artères coronaires et cavités cardiaques. Arch. Mal. Caur, 56, 121.

Steinberg, I., Baldwin, J. S., and Dotter, C. T. (1958). Coronary arteriovenous fistula. Circulation, 17, 372.

Swan, H., Wilson, J. N., Woodwark, G., and Blount, S. G. (1959). Surgical obliteration of a coronary artery fistula to right ventricle. Arch. Surg., 79, 820.

Trevor, R. S. (1911). Aneurysm of the descending branch of the right coronary artery, situated in the wall of the right ventricle, and opening into the cavity of the ventricle, associated with great dilatation of the right coronary artery and non-valvular infective endocarditis. Proc. roy. Soc. Med., 5, Sect. Study Dis. Child., p. 20.

Valdivia, E., Rowe, G. G., and Angevine, D. M. (1957). Large congenital aneurysm of the right coronary artery. Arch. Path., 63, 168.

Vela, J. E., Velasques, T., and Fuenmayor, A. (1951). Amplia communicacion congenital de la aorta con el ventriculo derecho a traves de la arteria coronaria derecho anomala. Arch. Inst. Cardiol. Méx., 21, 686.

Zuhdi, N., Kraft, D., Carey, J., and Greer, A. (1960). Coronary arteriovenous-like communications. Arch. Surg., 80, 178 . 